"This is the peer reviewed version of the following article: Drew J, Dollery B Australian Accounting Review (2015) which has been published in final form at

http://onlinelibrary.wiley.com/journal/10.1111/(ISSN)1835-2561. This article may be used for noncommercial purposes in accordance with Wiley Terms and Conditions for Self-Archiving." 


\title{
A Factor Analytic Assessment of Financial Sustainability: The Case of New South Wales Local Government
}

\begin{abstract}
Financial sustainability in local government remains a pressing problem which has seen a host of public policy interventions, including compulsory consolidation and performance monitoring through financial sustainability ratios. In September 2014, the New South Wales (NSW) Government announced a reform program centred on increasing scale in local government to make councils 'fit for the future'. We apply factor analysis to the ten financial ratios informing the NSW Government's reform initiative to identify the underlying factors for observed financial performance data. We find evidence indicating that three independent underlying factors account for the adopted measures of financial sustainability. The public policy implication arising from this study suggests that the reforms imposed by the NSW Government on NSW municipalities may only meet with limited success.
\end{abstract}

Keywords: latent factors, factor analysis, financial sustainability, local government, New South Wales. 


\section{Introduction}

The financial sustainability of local government continues to be a cause of great concern for regulators in Australia and abroad (Dollery et al. 2012). In an effort to monitor the financial problems which many municipalities face regulators are increasingly turning to financial ratio analysis (Drew and Dollery, 2013a). Yet just monitoring the decline of municipal fortunes is, in itself, unlikely to improve matters. What regulators and municipal executives need to know is why the financial sustainability of councils continues to deteriorate. One way of seeking to answer this question is to conduct multiple regression analysis to identify the determinants of the various financial ratios. However, this empirical approach has largely gone unrewarded owing inter alia to the need for a priori specification of regressors and functional form. By way of contrast, factor analysis (a technique which appears not to have previously been employed in the corpus of local government literature) offers a window into the latent factors responsible for the observed data - irrespective of whether they are currently able to be quantified. The incremental knowledge thus accrued can then assist regulators and public policy architects in their attempt to arrest the decline in municipal financial sustainability.

Despite the absence of an adequate empirical foundation, policy makers across the globe have assumed causes for local government financial sustainability problems. For example, the British Comprehensive Performance Assessment (CPA) program presumed management and leadership factors underpinned fiscal viability problems (Wilson 2004; Boyne and Enticott 2004). In New South Wales (NSW) local government the recent Independent Local Government Review Panel (ILGRP) assumed scale problems largely induced financial unsustainability (ILGRP 2013). This presumption that insufficient scale is responsible for the NSW local government financial sustainability predicament has now been promoted to the central thesis behind the NSW Government's 'Fit for the Future' local government reform program (Office of Local Government, 2014). 
However, it is highly unlikely that only a single factor causes financial sustainability problems. If all of the factors responsible for the observed financial sustainability data are not identified and addressed, then it is probable that public policy intervention will only meet with limited success. Given the significant cost, disruption and division involved in structural reforms, council consolidation should proceed only if it has a high probability of succeeding. Moreover, if latent factors driving financial performance are interdependent then this should be considered in policy formulation. In the latter case, public policies mistakenly directed at a single cause may result in unintended consequences or simply be ineffective.

Drawing on 2011 NSW local government data, in this paper we apply factor analysis to determine the number and degree of interaction for hypothesised underlying latent factors associated with financial sustainability measures. In this analysis we take as given the ability of the financial sustainability ratios developed by the Treasury Corporation of NSW (TCorp 2013) to measure sustainability and we do thus not provide a critique of these ratios.

Moreover, the local government reform agenda is principally motivated by the ten financial ratios and success is defined as having councils achieve thresholds on a subset of the ratios (office of Local Government (OLG) 2014) ${ }^{1}$.

\section{Accounting Ratios and Financial Sustainability in NSW Local Government}

The NSW Government established the ILGRP (2013: 4) in March 2012 to 'improve the strength and effectiveness of local government'. As part of its remit, the ILGRP focused on strengthening the financial sustainability of NSW local government. The NSW government requested TCorp to prepare Financial Sustainability Reports for each of the 152 NSW local authorities which were then used extensively by the Panel. Given the pivotal importance of financial sustainability in the deliberations of the ILGRP, completed reports were sought

\footnotetext{
${ }^{1}$ A detailed appraisal of the TCorp financial ratios is provided by Drew and Dollery (2013a).
} 
within a twelve month period. This vexing timeframe saw TCorp draw heavily on the work of the Queensland Treasury Corporation (QTC) which had produced regular financial sustainability reports on Queensland local authorities since July 2007 (TCorp 2013: 20). The TCorp Financial Sustainability Reports calculated ten financial sustainability ratios for NSW councils, classified under two broad categories: Financial Flexibility (Operating ratio and Own Source Operating Revenue ratio, Cash Expense, Unrestricted Current, Debt Service Cover and Interest Cover ratios) and Asset Renewal and Capital Works (Infrastructure Backlog, Asset Maintenance, Asset Renewal and Capital Expenditure ratios).

The ten ratios were then summarised as a single financial sustainability assessment ranging through 'very weak', 'weak', 'moderate', 'sound', 'strong' to 'very strong'. Five councils were assessed as 'very weak', including the Central Darling Council which was later placed under administration. A further 34 municipalities were assessed as 'weak', 79 as 'moderate', 32 as 'sound' and only two councils as 'strong'. No municipalities were assessed to be 'very strong'. All of the 'very weak' councils are classified as rural. Moreover, almost a quarter of the rural councils were assessed as 'weak', compared with $16 \%$ of metropolitan municipalities.

An empirical analysis of the relationship between financial sustainability and the TCorp ratios by Drew and Dollery (2013a) found only limited evidence of statistically significant associations with a comprehensive set of regressors that included population variables, socioeconomic indicators, demographic descriptors and infrastructure data. However, it should be noted that regression estimations, such as those performed by Drew and Dollery (2013a), cannot identify unmeasured or unmeasurable latent factors. Moreover, a single regression model cannot identify which latent constructs are responsible for specific data or ascertain the interaction between underlying factors. Factor analysis can overcome these issues when used 
in an exploratory fashion by identifying both the number of latent constructs and how financial ratios load on the factors.

The NSW Government's response to the ILGRP Final Report (2013) was issued by the Office of Local Government (OLG) in September 2014. Entitled Fit for the Future, its formal policy included a package totalling \$271 million to support councils to engage in large-scale mergers. In addition, local authorities have been given to the end of the current financial year 2014/15 to prepare detailed plans on how they meet Fit for the Future criteria and how they intend to improve performance to become 'fit for the future'. In this regard, while not prescribing forced amalgamation, the NSW Government has repeatedly claimed that 'for some councils joining forces with their neighbour may be the best option' (OLG 2014: 12).

Councils assessed to be 'fit for the future' will have access 'to a range of opportunities, including cheaper finance options, simplified reporting requirements, priority access to State funding and grants and options for additional planning powers' (OLG 2014: 12). Councils not deemed by the 'independent experts' to be 'fit for the future' will be referred to the Minister for unspecified action. According to Fit for the Future documentation, the first step for a council to assess their fitness is to decide whether they have sufficient scale and capacity. If this is not the case, then they are referred to the structural change 'roadmap' broadly consistent with the ILGRP Report recommendations. The ILGRP recommended some 63 local authorities be merged into 20 new entities.

If councils are deemed to have sufficient scale, then they must meet benchmarks for six of the TCorp financial ratios (Operating, Own Source, Asset Renewal, Infrastructure Backlog, Asset Maintenance, and Debt) and an undefined benchmark for Real Operating Expenditure over five years. No reason has been provided as to why four of the TCorp ratios fully endorsed by the ILGRP and which the NSW Government has committed to in other 
publications, such as Comparative Information on NSW Local Government - Measuring Local Government Performance (Department of Local Government 2014), are not required in the Fit for the Future proposals. One possibility resides in the fact that it is clear that most local authorities already met the benchmarks set by TCorp for two of the omitted ratios.

It is clear that accounting ratios lie at the heart of the NSW local government reform agenda and that both the ILGRP and NSW Government have determined that scale factors represent the single most important element driving the TCorp financial ratios. It need hardly be added that this is an empirical (and not conceptual) question which can only be settled by recourse to the data. However, to date no empirical evaluation of the latent factors driving the observed financial ratio data has been undertaken in NSW local government. This motivates the analysis presented in this paper.

Factor analysis is the technique most suited to answering this question because it (i) can test the association between variables and unmeasured or unmeasurable latent factors; (ii) does not require a priori assumptions; (iii) is not as sensitive as regression analysis to the quantum or choice of ratios chosen to exemplify financial sustainability; and (iv) aims to uncover the number and relationship of hypothesised latent factors. Thus factor analysis focuses on elucidating the underlying constructs that produce the observed data, rather than simply measuring and describing the association between different financial ratios.

To invoke a medical analogy; if we accept the TCorp, ILGRP and NSW Government contention that NSW local government is 'sick', then factor analysis seeks to illuminate the underlying cause of the symptoms, whereas correlation or regression analysis merely attempts to determine whether observed symptoms are associated with the purported disease. If the intent of local government reform is to make NSW local government 'healthy', then it would be best if policy makers understood the underlying constructs of the observed TCorp 
(2013) financial ratio data. This process in turn involves an appreciation of the literature on local government performance so that it might be applied to the identification of latent factors elucidated.

\section{Theoretical Perspectives on Financial Sustainability in Local Government}

In general, two major theoretical perspectives have been used to explain the financial performance of local government: (a) arguments centred on the scale of local authorities and (b) arguments premised on the existence of so-called external disability factors typically outside the discretion of municipal managers, which include demographic structure, socioeconomic factors, an inadequate revenue base and the like. In the Australian milieu, scale arguments have dominated policy discourse, even where stark evidence to the contrary has been presented (Drew and Dollery 2013b).

Put simply, scale economies are present when average total costs of production decrease as output expands (Ferguson 1969). It is held that most production units typically experience economies of scale, followed by constant returns to scale, and then diseconomies of scale. Scale economies arise due to the benefits of specialisation, improved purchasing power, greater utilisation of plant and other factors. By contrast, diseconomies of scale occur due largely to the greater complexities of managing bigger production units (Ferguson 1969).

Empirical evidence on scale economies in local government is mixed (see Dollery et al. 2012 for a survey of the international empirical literature). Moreover, in the Australian local government context, Byrnes and Dollery (2002) concluded that most Australian empirical work had been mis-specfied to such a degree that 'it has been possible to conclude that no satisfactory Australian study has yet been conducted into economies of scale in municipal service provision' (Byrnes and Dollery 2002: 404). However, more recent Australian work suggests that economies of scale may not be as dominant a determinant of municipal 
performance in Australia as previously thought (see, for instance, Drew et al. 2013a; Drew and Dollery 2013b, Drew et al. 2012; Drew et al. 2013b).

Disability factors in local government cover a host of demographic and socio-economic indicators, such as the age profile of a local government area, wage levels, and formal education qualifications, as well as physical characteristics, like climatic considerations, distance to large centres, and topography. It is hypothesised in the literature that disability factors place greater demands on local government services and hence impose more acute budgetary pressures. This is supported by a body of empirical evidence. For example, Andrews et al. (2005: 653) concluded that 'local government service performance is consistently constrained by external circumstances'. Similarly, a study by Boyne et al. (2001: 875) suggested that 'local budgetary outcomes are constrained by movements in workloads, as measured by service needs, and munificence, as measured by financial resources'. Disability factors have been considered determinants of local government performance in American work by Fisher (1961) and more recently Holcombe and Williams (2008).

However, despite the frequent use of exogenous variables as disability factors in Australian econometric modelling, there is no direct evidence that it is associated with service need in local government. Indeed, given the limited 'services to property' service responsibilities of Australian municipalities, with few 'services to people' obligations, it is far from certain that socio-economic disability factors are a major determinant of council performance. However, given the wave of performance monitoring sweeping through the Australian local government sector (TCorp 2013; Department of Local Government, Community Recovery and Resilience 2013), there is a pressing need to establish empirically whether disability factors are in fact a significant cost driver in Australian local government. 
Whilst scale and disability factors have dominated much of the empirical literature, recent work has underlined the potential for management capacity to influence local government performance. For instance, in a survey of municipal officers Boyne and Enticott (2004) found that staff in poorly performing councils believed that senior management and political leaders did little to drive performance improvement, which contrasted starkly with the assessments of officers working at 'excellent' and 'good' local authorities. In addition, in an empirical investigation of the effect of external constraints on municipal performance, Andrews et al. (2005: 654) suggested that it was 'equally plausible that the behaviour and choices of local policy-makers are the missing part of the performance equation.' Largely due to data availability problems, this emerging hypothesis for local government performance has remained untested in the Australian context.

\section{Empirical Technique}

Peterson (2000: 262) has observed that 'simply stated the objective of factor analysis is analytical parsimony tempered with interpretative plausibility'. Factor analysis examines the covariation between observations in order to identify unmeasured linear composite latent factors (Kim and Mueller 1978). It may be used in an exploratory fashion 'a means of exploring the underlying factor structure without prior specification of number of factors and their loading' (Kim and Mueller 1978: 85), or alternatively in order to reduce a large number of variables into a more manageable set or index. Given that our objective in this paper is to investigate how many underlying factors exist and the nature of the hypothesised latent constructs, our analysis is exploratory in nature. While we draw on extant economic theory, we make no a priori assumptions as to whether theory is relevant in the NSW municipal context. Moreover, determining the number of latent constructs is a critical matter given that the NSW state government response to the ILGRP recommendations gives primacy to just 
one factor (i.e. scale), and the presence of additional factors or interactions between factors may well determine the success of the NSW local government reform process.

This paper uses the Principal Factor approach - rather than the Principal Component approach which invokes the crucial assumption that all variance can be assumed to be attributable to the common factors only. The analysis examines co-variation between financial sustainability ratios for the 118 (of 152) NSW municipalities which had complete data sets at the time of writing (as per the TCorp (2012) Report). Three tests were then applied to ascertain the number of major factors: Kaiser's rule, Cattell's Scree test and comparison with theory (consistent with Willis et al. 2005). Table 1 provides a summary of the data used and definitions of financial sustainability ratios. A brief discussion of the merits of these tests is apposite given the critical policy implications associated with the number of latent constructs elucidated.

\section{[INSERT TABLE 1 HERE]}

Kaisers rule (K1) is undoubtedly the most popular method for determining the number of hypothetical latent factors, despite some empirical evidence suggesting that it performs rather poorly (Hayton et al. 2004). However, much of the criticism can be traced to misconceptions regarding its analytical foundations since it is often used as a rule for determining the definitive number of latent factors rather than the upper bound (Zwick and Velicer 1986). Users also tend to ignore the fact that Guttman's proof of factor prediction certainty is based on the population correlation matrix and not the sample. In this regard, Hayton et al. (2004: 193) observed that 'for finite samples, sampling error adds to the rank of a given correlation matrix, and thus the K1 criterion may tend to overestimate the number of factors'.

Part of the attraction of Kaiser's rule resides in its simplicity: major latent factors are identified as those with eigenvalues (the amount of variance accounted for by each factor) 
exceeding 1. Moreover, many of the criticisms can be ameliorated by applying complementary tests, such as Cattell's Scree test (which plots eigenvalues against the number of factors and seeks to determine the point at which a scree develops as a result of relatively small variances prompted by minor factors), surveying significant proportions of the entire population and recognising that $\mathrm{K} 1$ only indicates the highest number of major hypothesised latent factors (and that a smaller number may nonetheless exist). In our case, approximately $80 \%$ of NSW councils are represented in the factor analysis.

The next major objective of our analysis was to determine the degree of interaction between latent factors. In this regard, both orthogonal rotations (suggesting independence) and oblique rotations (indicating correlations between factors) were conducted in response to Merenda (1997). If similar results were obtained, then orthogonal relationships could be posited, whereas dissimilar results would suggest oblique associations between factors. This point is important in a public policy context because any action intended to address any one of the underlying factors causing the observed data may have significant unintended consequences if the factors are interdependent.

Finally, the nature of the latent factors was hypothesised on the basis of how the financial sustainability ratios loaded on each factor. In this regard, the significant loadings were considered to be at a minimum 0.40 in response to Peterson (2000) who criticised the common cut-off of 0.30 after noting that it is the loading squared which contributes to variance. Moreover, using a higher threshold avoids the occurrence of 'complex' factors and hence eases interpretability, although it is important to remain cognisant of the fact that ratios noted for each factor are the dominant loadings and that other less significant loadings are also constituents of the reported Factors. The sign of the loading was also considered wherein a negative loading indicated the factor produced causation in the opposite direction to other loadings. We also employed cross-section regressions in one instance to confirm whether the 
latent construct assigned - predicated on theoretical considerations - was supported by econometric evidence. This was particularly appropriate given the emphasis placed on scale by both the ILGRP (2013) and OLG(2014) and the fact that recourse has long been made to econometric evidence to ascertain whether economies of scale exist in local government (Drew, Kortt and Dollery 2012).

\section{Number of Latent Factors}

Eigenvalues for the unrotated factor solutions are detailed in Table 2. As we can see, the eigenvalues suggest a maximum of three major latent factors for the observed data under the $\mathrm{K} 1$ criterion: it is not reasonable to eliminate the three factor solution on a trivial deviance from an eigenvalue of 1 . However, as detailed in section 3, this result does not eliminate the possibility of two or one latent factors, the latter representing the implied position of the NSW Government. To move beyond this upper bound result, a Scree test was then employed. This test suggests that three major latent factors explain most of the covariation in the observed data.

\section{[INSERT TABLE 2 HERE]}

There are two additional reasons for rejecting the possibility of one or two solutions which would be otherwise equally compatible with the K1 result. Firstly, the weight of scholarly literature on scale effects is consistent with Factor 2: acceptance of this implies at least two factors. It is worthwhile noting that the two factor solution still contains loadings very similar to Factor 1. Finally, the loadings on Factor 3 are consistent with a management explanation which is in turn consistent with some existing empirical evidence (Boyne and Enticott, 2004). Moreover, it makes intuitive sense that management decisions would influence municipal financial sustainability: only if the decisions of electoral representatives and senior management had consistently insignificant pecuniary implications could one argue against its 
inclusion as a latent factor. However, it would be reasonable, on the basis of the analysis, to suggest that the Factor 3 had less explanatory power than the first two.

Public policy implications arising from the results are significant. The NSW Government response to the ILGRP (2013) Report requires councils to submit their 'fit for the future' proposals by June 2015. The foremost criterion assessing the 'fit for the future' status of a given council is scale. Should a council not have 'adequate' scale, then it is directed to the 'Structural Change Roadmap', which would set in train an amalgamation to achieve the minimum population size decreed by the ILGRP. If a council does have adequate scale, then it is directed to address the subordinate criteria of sustainability, efficiency and effective infrastructure and service management. While scale is being used as a principal determinant of whether a council will be assessed as 'fit for the future' the analysis indicates that there are an additional two major underlying factors that should be considered.

\section{Nature of Latent Factors}

Table 3 describes the factor loadings for each of the three major hypothetical latent factors. Both orthogonal and oblique rotations are reported for comparative purposes. The close similarity between the two solutions indicates that the orthogonal rotation is satisfactory. What this means is that our evidence indicates that the latent factors are largely independent. This has implications for public policy formulation since it suggests that action taken to ameliorate the effects of a single latent factor, such as a boundary change to address scale factors, is unlikely to affect the other causes of local government financial sustainability, like management factors. As a result, there is limited scope for regulatory intervention to produce unintended consequences. However, it also means that policy intervention addressing just one factor - in the current NSW case the scale factor - may meet with limited success since two of the major latent constructs driving the observed data are not addressed by the reform 
program. In order to secure significant improvements, the evidence indicates that policy intervention should be tailored to address all three major latent factors simultaneously.

\section{[INSERT TABLE 3 HERE]}

Table 3 provides details of how the TCorp (2012) ratios load on each of the three factors identified. Notably, the dominant loadings for each factor are unique which assists in the interpretation of the latent constructs. Moreover, complex factors have been entirely avoided.

Factor 1 loads most heavily on the two ratios which deal solely with debt. This means that we can deduce that Factor 1 predominantly causes changes in debt ratios, but has relatively little effect on other observed indicators (such as annualised operating results). The fact that the two observed debt ratios are driven by the same latent construct is in itself not a surprising result. However, the absence of the same two ratios from the significant loading summary of the other Factors is quite significant: the highest loading for these two ratios on Factor 2 is 0.12 and for Factor 3 is 0.01 . This indicates that the observed financial ratios relating to debt are principally the measured outcome of just a single independent latent construct and that policy intervention taken in relation to other latent factors will not result in any discernible improvement to the debt ratios. The construct that best explains the observed loadings suggests a largely unreported cause of financial sustainability is the effect of past decisions.

These inherited problems refer to the accumulated impact of previous budgetary outcomes and expenditure commitments and manifests itself as long-term debt. It is consistent with the empirical evidence of Boyne et al. (2001: 875) who observed that 'external pressures and the legacy of previous budgetary decisions are major drivers of expenditure change.' This explanation suggests that councils burdened with high levels of debt will struggle to achieve financial sustainability. It is important to note that these ratios reflect the accumulation of earlier budgetary outcomes over a number of years whilst the remaining financial flexibility 
ratios (operating, own source, unrestricted current and cash expense ratios) predominantly reflect events limited to the current financial year. It is thus quite possible that inherited problems from the past might be reflected in poor debt ratios, but may not be indicated in the other financial flexibility indicators for a given year.

The second factor is hypothesised to be caused by economies of scale and density. The first indication that a scale explanation is warranted is the high loading on the own source ratio (loading in the opposite direction to the Unrestricted, Cash Expense and Asset Maintenance ratios). In Australia, fiscal equalisation grants, which represent the major component of 'other source' revenue, are based heavily on population measures and spatial remoteness criteria (correlated strongly with density) (Drew and Dollery 2013a). This thus suggests the possibility of economies of scale and density. Confirmation of this hypothesis can be provided by recourse to econometric evidence - if economies of scale and density are indeed the best explanation for the factor then it would be reasonable to expect that population size, number of employing businesses and population density would be statistically significant regressors for econometric models employing the dominant factor loadings (for Factor 2) as regressands ${ }^{2}$. In this regard it is noteworthy that three of the four linear models report population size as a significant regressor, and that the two models with the highest coefficient of determination also report density as a significant determinant. Finally, the weight of empirical literature supports the contention that scale effects will have a direct impact on municipal liquidity (cash expense and unrestricted ratios) (see, for instance, Jones and Walker (2007)).

\footnotetext{
${ }^{2}$ The full specification of regressors is as follows: population size, population density, average wage, proportion of individuals over 65 years of age, length of roads (in kms), proportion of individuals from a nonenglsih speaking background, proportion of individuals identifying as Aboriginal and Torres Strait Islander, number of employing businesses and the proportion of individuals under 15 years of age. This is consonant with the models employed by Drew and Dollery 2013a, 2013b.
} 
In summary, scale (but not density) has been identified by the ILGRP and the NSW Government as the preeminent factor determining a council's 'fitness' for the future. However, the findings of this paper present hitherto unconsidered complications for the NSW local government reform process. In essence, scale is just one of three factors driving the observed financial ratio data and yet the NSW Government's attempt to improve financial sustainability seems to largely ignore the other two independent latent constructs. Whereas there is access to cheaper finance for 'fit for the future' councils, there is nonetheless no suggestion that the NSW Government will pay down debt. Secondly, economies of density are also indicated by our analysis and it is difficult to see how council mergers can address population density directly. The final matter to note is that the eigenvalue for this factor suggests it is not the construct responsible for the majority of the observed variance.

\section{[INSERT TABLE 4 HERE]}

The final factor is only marginally categorised as a major latent identity. It loads heavily on the operating ratio, asset renewal ratio and capital expenditure ratio. All three ratios are directly affected by annualised decisions taken by senior municipal managers: we can thus expect this effect will be greater than for other ratios, such as infrastructure backlog and debt ratios, which are determined by cumulative effects over many years, or the own source ratio, which is determined by exogenous factors. For example, the asset renewal ratio and capital expenditure are both the direct results of two actions: in the first instance decisions on the quantum of asset renewal and capital investment, and more contentiously in the second instance, decisions regarding the remaining effective life and residual value of non-current assets (which are translated into depreciation values) (see, for instance, Drew and Dollery 2014). Similarly, the operating ratio involves a number of conscious decisions relating to expenditure and revenue for which there are annualised consequences. In section 2 , the emerging empirical evidence supporting a management hypothesis was presented. 
Unfortunately, there is a paucity of Australian evidence relating to the effect of senior management on municipal performance due to a lack of available data. 7.

\section{Concluding Remarks}

By the end of June 2015, all NSW councils will have to submit their proposals on how they will be 'fit for the future'. The preeminent factor used to determine fitness will be appropriate scale. Yet in this paper, our empirical analysis shows that there are three - and not one major latent factors driving the observed financial sustainability ratios which prompted the reform process in the first place. Moreover, we have established that the three factors - scale and density, legacy, and management competency - act largely independently.

This result should be of considerable interest to public policymakers. Under the present policy trajectory, the best case scenario is that the NSW Government reform program may have relatively little impact on the measures of financial sustainability adopted by the government, owing to the fact that two of the major latent constructs have gone largely unaddressed. By contrast, the worst case scenario is that the specific combinations of municipal mergers recommended by the ILGRP will not improve the financial ratios at all (see Drew and Dollery 2013a). These outcomes should be set against the 'investment' of 'up to $\$ 1$ billion' (OLG 2014: 4), severe disruption to local government functioning, distress caused to affected staff, and unnecessary community division.

It may be objected that other explanations may exist for the nature of hypothesised latent factors. However, we have only proposed the strongest hypotheses on the basis of existing supporting evidence. The task now is to replicate this empirical method in other local government systems for comparative purposes, as well as conducting alternative studies designed to test each specific hypothesis. Further empirical evidence may uncover alternate explanations or contrasting factor interactions which could well explain why public policy 
efforts aimed at improving municipal financial sustainability have previously gone largely unrewarded. 


\section{References}

Andrews R., G. Boyne, J. Law, and Walker, R. 2005, 'External Constraints on Local Service Standards: The Case of Comprehensive Performance Assessment in English Local Government', Public Administration, 83, 3: 639-656.

Boyne G., R. Ashworth, and Powell, M. 2001, 'Environmental Change, Leadership

Succession and Incrementalism in Local Government', Journal of Management Studies, 38, 6: 859-878.

Boyne G., and Enticott, G. 2004, 'Are the Poor Different? The Internal Characteristics of Local Authorities in the Five Comprehensive Performance Assessment Groups', Public Money \& Management, 24, 1: 11-18.

Byrnes J., and Dollery, B. 2002, 'Do Economies of Scale Exist in Australian Local Government? A Review of the Research Evidence1', Urban Policy and Research, 20, 4: 391414.

Department of Local Government Community Resilience and Recovery (DLGCRR) 2013, Financial Management (Sustainability) Guideline, DLGCRR, Brisbane.

Dollery, B. E., Crase, L. and Johnson, A. 2006, Australian Local Government Economics, Sydney, University of New South Wales Press.

Dollery B., B. Grant and Kortt, M. 2012, Councils in Cooperation - Shared Services and Australian Local Government, Federation Press, Sydney.

Drew J., and Dollery, B. 2013a, 'Is The Game Worth The Candle? Estimating the Impact of the Proposed Greater Sydney Metropolitan Amalgamations on Municipal Financial Sustainability', Public Money \& Management In Print.

Drew J., and Dollery, B. 2013b, 'Would Bigger Councils Yield Scale Economies in the Greater Perth Metropolitan Region? A Critique of the Metropolitan Local Government Review for Perth Local Government', Australian Journal of Public Administration, In Print. 
Drew, J. and Dollery, B. 2014, 'Inconsistent Depreciation Practice and Public Policymaking: Local Government Reform in New South Wales', Australian Accounting Review, In Print.

Drew J., M. Kortt and Dollery, B. 2012, 'Economies of Scale and Local Government Expenditure: Evidence from Australia', Administration \& Society OnlineFirst.

Drew J., M. Kortt and Dollery, B. 2013a, 'A Cautionary Tale: Council Amalgamations in Tasmania and the Deloitte Access Economics Report', Australian Journal of Public Administration, 72, 1: 55-65.

Drew J., M. Kortt, and Dollery, B. 2013b, 'Did the Big Stick Work? An Empirical Assessment of Scale Economies and the Queensland Forced Amalgamation Program', Local Government Studies, In Print.

Ferguson C. 1969, Neoclassical Theory of Production and Distribution, Cambridge University Press, Cambridge.

Fisher G. 1961, 'Determinants of State and Local Government Expenditures: A Preliminary Analysis', National Tax Journal, 14, 4: 349-355.

Hayton J., D. Allen and Scarpello, V. 2004, 'Factor Retention Decisions in Exploratory Factor Analysis: A Tutorial on Parallel Analysis', Organizational Research Methods, 7, 2: 191-205.

Holcombe R., and Williams, D. 2008, 'The Impact of Population Density on Municipal Government Expenditures', Public Finance Review, 36, 3: 359-373. Independent Local Government Review Panel (ILGRP) 2013, Future Directions for NSW Local Government - Twenty Essential Steps, ILGRP, Sydney. Jones S. and Walker, R. 2007, 'Explanators of Local Government Distress', ABACUS, 43, 3: $396-418$.

Kim, J. and Mueller, C. 1978. Factor Analysis - Statistical Methods and Practical Issues, Sage University Series, California. 
Kloha P., C. Weissert and Kleine, R. 2005, 'Someone to Watch Over Me: State Monitoring of Local Fiscal Conditions', American Review of Public Administration, 35, 3: 236-255.

Merenda P. 1997, 'A Guide to the Proper Use of Factor Analysis in the Conduct and Reporting of Research: Pitfalls to Avoid', Measurement and Evaluation in Counselling and Development, 30, 3: 156-164.

Office of Local Government (OLG) 2014, Fit for the Future - A Blueprint for the Future of Local Government, OLG, Sydney.

Peterson R. 2000, 'A Meta-Analysis of Variance Accounted for and Factor Loadings in Exploratory Factor Analysis', Marketing Letters, 11, 3: 261-275.

Pricewaterhouse Coopers (PWC) 2006, National Financial Sustainability Study of Local Government, PWC, Sydney.

TCorp 2013, Financial Sustainability of the New South Wales Local Government Sector, TCorp, Sydney.

Willis K., N. Powe and Garrod, G. 2005, 'Estimating the Value of Improved Street Lighting: A Factor Analytical Discrete Choice Approach', Urban Studies, 42, 12: 2289-2303.

Wilson J. 'Comprehensive Performance Assessment - Springboard or Dead-Weight?' Public Money \& Management, 24, 1: 63-68.

Zwick W. and Velicer, W. 1986, 'Comparison of Five Rules for Determining the Number of Components to Retain', Pyschological Bulletin, 99, 3: 432-442. 
Table 1: Definitions and Measures of Central Tendency of Regression Variables

\begin{tabular}{|c|c|c|c|}
\hline Variable & Definition & Mean & $\begin{array}{l}\text { Standard } \\
\text { Deviation }\end{array}$ \\
\hline \multicolumn{4}{|l|}{ Factor Variables } \\
\hline Operating ratio & $\begin{array}{l}\text { (operating revenue } \dagger \text { - operating } \\
\text { expenses) / operating revenue } \dagger \text {. } \\
\text { Benchmark }>-4.0 \% \text {. }\end{array}$ & -6.818 & 9.833 \\
\hline $\begin{array}{l}\text { Own Source Revenue } \\
\text { ratio }\end{array}$ & $\begin{array}{l}\text { rates, utilities and charges / total } \\
\text { operating revenue }+ \text {. Benchmark } \\
>60.0 \% \text {. }\end{array}$ & 56.561 & 13.622 \\
\hline $\begin{array}{l}\text { Unrestricted Current } \\
\text { ratio }\end{array}$ & $\begin{array}{l}\text { current assets less restrictions / } \\
\text { current liabilities less specific } \\
\text { purpose liabilities. Benchmark } \\
>1.5 \text {. }\end{array}$ & 3.601 & 2.202 \\
\hline Interest Cover ratio & $\begin{array}{l}\text { EBITDA / interest expense. } \\
\text { Benchmark > 4.0. }\end{array}$ & 84.128 & 335.350 \\
\hline $\begin{array}{l}\text { Infrastructure Backlog } \\
\text { ratio }\end{array}$ & $\begin{array}{l}\text { estimated cost to bring assets to } \\
\text { a satisfactory condition / total } \\
\text { infrastructure assets. } \\
\text { Benchmark }<0.02 \text {. }\end{array}$ & 0 & 0.142 \\
\hline Debt ratio & $\begin{array}{l}\text { EBITDA / (principal } \\
\text { repayments + borrowing costs). }\end{array}$ & 35.768 & 270.826 \\
\hline $\begin{array}{l}\text { Capital Expenditure } \\
\text { ratio }\end{array}$ & $\begin{array}{l}\text { Benchmark }>2.0 \text {. } \\
\text { annual capital expenditure / } \\
\text { annual depreciation. Benchmark }\end{array}$ & 1.204 & 0.702 \\
\hline Cash Expense ratio & $\begin{array}{l}>1.1 \text {. } \\
\text { (current cash and equivalents / } \\
\text { (total expenses - depreciation - } \\
\text { interest costs)) x } 12 . \text { Benchmark } \\
>3.0 \text { months. }\end{array}$ & 5.128 & 4.744 \\
\hline Asset Renewal ratio & $\begin{array}{l}\text { Asset renewals / depreciation of } \\
\text { building and infrastructure } \\
\text { assets. Benchmark }>1.0 \text {. }\end{array}$ & 0.665 & 0.495 \\
\hline $\begin{array}{l}\text { Asset Maintenance } \\
\text { ratio }\end{array}$ & $\begin{array}{l}\text { actual asset maintenance / } \\
\text { required asset maintenance. } \\
\text { Benchmark }>1.0 \text {. }\end{array}$ & 0.882 & 0.555 \\
\hline \multicolumn{4}{|l|}{ Regressors } \\
\hline Population (ln) & $\begin{array}{l}\text { natural log of resident } \\
\text { population }\end{array}$ & 9.959 & 1.372 \\
\hline Population density (ln) & $\begin{array}{l}\text { natural log of population } \\
\text { density }\end{array}$ & 2.952 & 3.314 \\
\hline $\begin{array}{l}\% \text { population under } 15 \\
\text { years }\end{array}$ & $\begin{array}{l}\text { proportion of residents under } 15 \\
\text { years of age }\end{array}$ & 19.468 & 2.531 \\
\hline $\begin{array}{l}\% \text { population over } 65 \\
\text { years }\end{array}$ & $\begin{array}{l}\text { proportion of residents over } 65 \\
\text { years of age }\end{array}$ & 16.503 & 4.191 \\
\hline $\begin{array}{l}\% \text { population ATSI } \\
(\ln )\end{array}$ & $\begin{array}{l}\text { natural log of proportion of } \\
\text { Aboriginal and Torres Strait }\end{array}$ & 1.035 & 1.215 \\
\hline
\end{tabular}




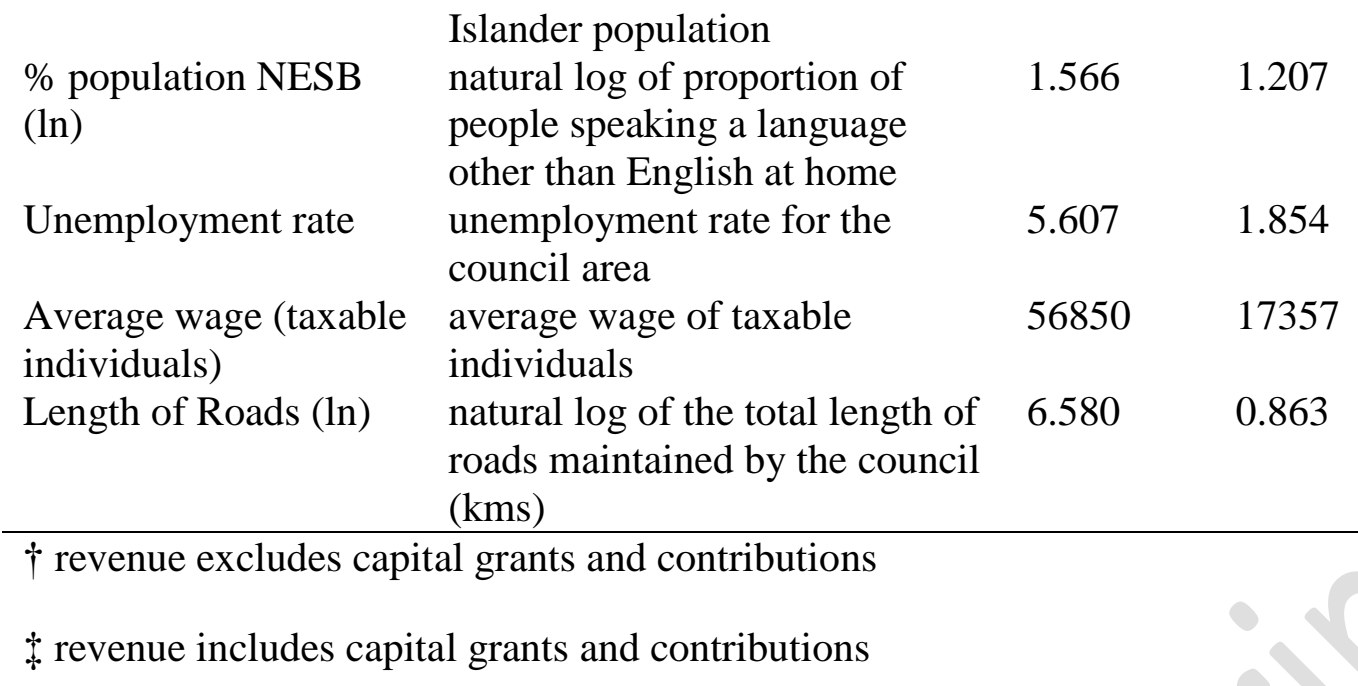

Table 2: Eigenvalues of Unrotated Factor Analysis

\begin{tabular}{ll}
\hline Factors & Eigenvalue \\
\hline Factor 1 & 1.642 \\
Factor 2 & 1.179 \\
Factor 3 & 0.993 \\
Factor 4 & 0.410 \\
Factor 5 & 0.220 \\
Factor 6 & 0.010 \\
\hline
\end{tabular}

Table 3: Significant Factor Loading for a 3 Latent Factor Model

\begin{tabular}{lll}
\hline Factors & $\begin{array}{l}\text { Factor Loading } \\
\text { (orthogonal) }\end{array}$ & Factor Loading (oblique) \\
\hline $\begin{array}{l}\text { Factor 1 Disadvantage/Legacy } \\
\text { of Previous Budgets }\end{array}$ & & \\
$\begin{array}{l}\text { Interest Cover ratio } \\
\text { Debt ratio }\end{array}$ & 0.895 & 0.891 \\
\hline Factor 2 Size/Scale & 0.873 & 0.879 \\
Unrestricted ratio & 0.641 & 0.642 \\
Own Source ratio & -0.474 & -0.474 \\
Cash Expense ratio & 0.524 & 0.522 \\
Asset maintenance & 0.388 & 0.392 \\
\hline Factor 3 Management & & \\
Operating ratio & 0.520 & 0.520 \\
Asset renewal ratio & 0.618 & 0.619 \\
Capital Expenditure ratio & 0.574 & 0.574 \\
\hline
\end{tabular}


Table 4: Statistically Significant Regressors for Dominant Loadings Relating to Latent Factor 2

\begin{tabular}{|c|c|c|c|}
\hline $\begin{array}{l}\text { Unrestricted } \\
\text { (In) }\end{array}$ & $\begin{array}{l}\text { Own Source } \\
\text { ratio }\end{array}$ & $\begin{array}{l}\text { Cash Expense } \\
\text { (In) }\end{array}$ & $\begin{array}{l}\text { Asset } \\
\text { Maintenance } \\
(\text { In) }\end{array}$ \\
\hline $\begin{array}{l}\text { Population } \\
(\operatorname{In})^{* * *}\end{array}$ & Population (In)* & Average wage** & $\begin{array}{l}\text { Population } \\
(\ln )^{* *}\end{array}$ \\
\hline Density $(\ln )^{* * *}$ & Over 65 years* & & Business $(\ln )^{* *}$ \\
\hline NESB $(\ln )^{* *}$ & Density $(\ln )^{* *}$ & & \\
\hline Business $(\ln )^{* * *}$ & $\begin{array}{l}\text { Total roads } \\
(\ln )^{* * *}\end{array}$ & & \\
\hline
\end{tabular}

Average

wage $* * *$

Total roads

$(\ln )^{* * *}$

\begin{tabular}{llll}
\hline$R^{2}=0.307$ & $R^{2}=0.641$ & $R^{2}=0.221$ & $R^{2}=0.100$ \\
\hline
\end{tabular}

$* p<0.10, * * p<0.05, * * * p<0.01$ 